\title{
ГЕНЕТИЧНИЙ АНАЛІЗ ОСНОВНИХ ОЗНАК ЯКОСТІ ГРАНУЛЯРНОГО КРОХМАЛЮ У КУКУРУДЗИ НА ОСНОВІ МУТАЦÏ̈ SU1
}

\author{
С. М. Тимчук ${ }^{1}$, М. М. Мартинюк ${ }^{1}$, В. В. Поздняков ${ }^{1}$, В. М. Тимчук ${ }^{1}$, \\ О. В. Анциферова ${ }^{1}$ Ю. В. Харченко ${ }^{2}$, Л. Я. Харченко ${ }^{2}$ \\ ${ }^{1}$ Інститут рослинництва ім. В. Я. Юр'єва НААН \\ ${ }^{2}$ Устимівська дослідна станція рослинництва
}

Встановлено, що основні ознаки якості гранулярного крохмалю у носіїв ендоспермової мутації кукурудзи $s u_{l}$ мають кількісну природу і суттєво залежать від взаємодій ген : генотип. Діаметр крохмальних гранул і вміст крохмалю в зерні носіїв мутації $s u_{1}$ успадковуються за типом позитивного наддомінування, а вміст амілози в крохмалі - за типом неповного домінування із суттєвим вкладом до дисперсії адитивних ефектів. Виділено лінії носії мутації $s u_{1}$ з високими ефектами комбінаційної здатності за основними ознаками якості гранулярного крохмалю. аналіз

Кукурудза, мутант sи, якість гранулярного крохмалю, генетичний

Вступ. Кукурудзяний крохмаль є одним з найбільш поширених видів рослинної біосировини і широко використовується в харчових, фармацевтичних та технічних виробництвах $[1,2]$. Однак якість кукурудзяного крохмалю далеко не завжди задовольняє специфічні вимоги цих виробництв і потребує поліпшення, найбільш результативним і економічно вигідним методом якого вважається генетичне поліпшення [3].

Відомо, що кукурудза серед культурних рослин вирізняється найбільш широким генетичним різноманіттям за вуглеводним складом зерна, яке може бути з успіхом використане в селекції $[4,5]$. На даний час у кукурудзи ідентифіковано серію моногенних мутацій, які викликають суттєвий ефект за вмістом та фракційним складом крохмалю $[6,7]$ і встановлено, що цей ефект супроводжується зміненням морфології крохмальних гранул $\mathrm{i}$ технологічних властивостей крохмалю $[8,9]$.

Серед відомих крохмаль - модифікуючих мутацій кукурудзи на практичну увагу заслуговує, зокрема, мутація $s u_{l}$, яка значно знижує активність крохмаль - дерозгалужуючого ферменту, пригнічує утворення амілопектину і підвищує вміст водорозчинних полісахаридів і цукрози в зерні та амілози в крохмалі [10].

(C) С. М. Тимчук, М. М. Мартинюк, В. В. Поздняков, В. М. Тимчук, О. В. Анциферова, Ю. В. Харченко, Л. Я. Харченко. 2012.

ISSN 0582-5075. Селекція і насінництво. 2012. Випуск 102. 
Однак, незважаючи на проведені до цього часу дослідження, характер успадкування основних ознак якості гранулярного крохмалю у носіїв мутації $s u_{l}$ не встановлено і це обмежує оцінку перспектив їх використання при створенні джерел високоякісної крохмаленосної сировини.

Наведені розуміння і склали підстави для проведення наших досліджень.

Мета і завдання досліджень. Метою досліджень був генетичний аналіз основних ознак якості гранулярного крохмалю в системах регулярних схрещувань ліній кукурудзи - носіїв мутації $s u_{l}$.

Конкретні завдання досліджень передбачали:

встановлення ефекту мутації $s u_{1}$ за основними ознаками якості гранулярного крохмалю у ліній та гібридів кукурудзи;

аналіз характеру успадкування основних ознак якості гранулярного крохмалю і генетичних компонентів дисперсії у носіїв мутації $s u_{l}$;

визначення ефектів комбінаційної здатності ліній кукурудзи - носіїв мутації $s u_{l}$ за основними ознаками якості гранулярного крохмалю і виділення кращих ліній для подальшого використання в селекції.

Матеріал і методи досліджень. Матеріалом для досліджень послугували шість неспоріднених за походженням інбредних ліній кукурудзи носіїв мутації $s u_{1}$ і серія простих гібридів, отриманих при їх діалельних схрещуваннях за другим методом Гріфінга. Контролями в експерименті були шість ліній та 15 простих гібридів кукурудзи традиційного типу.

Лінії і гібриди кукурудзи вирощували в 2009 році на Устимівській дослідній станції рослинництва, яка розташована в Глобинському районі Полтавської області і належить до зони Південного Лісостепу України та в Державному підприємстві «Дослідне господарство Елітне», яке розташоване в Харківському районі Харківської області і належить до зони Східного Лісостепу України.

Польові досліди проводили згідно загальноприйнятої методики польового експерименту [11] з урахуванням зональних особливостей вирощування кукурудзи.

При визначенні розмірів крохмальних гранул використовувався цифровий аналіз мікрофотографій. Для їх отримання зерно фіксувалося протягом 72 годин в суміші спирт : гліцерин : вода в співвідношенні 1:1:1 3 додаванням в якості антисептику $0,01 \%$ азиду натрію, а потім розтиралося в фарфоровій ступці. Фотографування препаратів гранул виконувалося на мікроскопі "Биолам-15" (об'єктив × 40) з використанням комп'ютерної цифрової мікроскопічної відеокамери DCM-300. Розміри гранул визначали за допомогою програми цифрового аналізу зображення Scope Photo. B кожному експериментальному зразку аналізували по 1500 гранул.

Вміст крохмалю в зерні визначали поляриметричним методом Еверса, а вміст амілози в крохмалі - колориметричним методом В. О. Juliano [12]. Вміст крохмалю в зерні обчислювали у відсотках до абсолютно сухої речовини (а.с.p.), а вміст амілози в крохмалі - у відсотках. 
Отримані результати піддавали статистичній обробці методами дисперсійного та діалельного аналізу з використанням алгоритму Хеймана $[13,14]$.

Результати та їх обговорення. Отримані результати показали, що за діаметром крохмальних гранул і вмістом крохмалю в зерні лінії - носії мутації $s u_{1}$ значно поступаються лініям традиційного типу, а за вмістом амілози в крохмалі - переважають їх (табл. 1).

Таблиця 1

Мінливість основних ознак якості гранулярного крохмалю у ліній кукурудзи традиційного типу і ліній - носіїв мутації $s u_{1}$ (середнє за результатами випробувань в двох екологічних зонах, 2009 р.)

\begin{tabular}{|c|c|c|c|c|c|c|}
\hline \multirow{2}{*}{ Типи ліній } & \multicolumn{2}{|c|}{$\begin{array}{c}\text { Діаметр крохма- } \\
\text { льних гранул, мкм }\end{array}$} & \multicolumn{2}{|c|}{$\begin{array}{l}\text { Вміст крохмалю в } \\
\text { зерні, \% до а.с.р. }\end{array}$} & \multicolumn{2}{|c|}{$\begin{array}{l}\text { Вміст амілози в } \\
\text { крохмалі, \% }\end{array}$} \\
\hline & $\begin{array}{l}\text { мін.- } \\
\text { макс. }\end{array}$ & середній & $\begin{array}{l}\text { мін.- } \\
\text { макс. }\end{array}$ & середній & $\begin{array}{l}\text { мін.- } \\
\text { макс. }\end{array}$ & середній \\
\hline $\begin{array}{l}\text { Традицій- } \\
\text { ний }\end{array}$ & $\begin{array}{l}9,6- \\
10,8\end{array}$ & 10,1 & $\begin{array}{l}63,9- \\
66,3\end{array}$ & 64,7 & $\begin{array}{l}26,3- \\
27,2\end{array}$ & 26,8 \\
\hline Мутанти $s u_{l}$ & $4,8-5,4$ & 5,2 & $\begin{array}{l}36,7- \\
39,0 \\
\end{array}$ & 37,7 & $\begin{array}{l}31,9- \\
33,6 \\
\end{array}$ & 32,7 \\
\hline HIP $_{0,95}$ & 0,3 & 0,4 & 0,7 & 0,9 & 0,4 & 0,8 \\
\hline
\end{tabular}

Схожі відмінності носіїв мутації $s u_{l}$ від кукурудзи традиційного типу зареєстровано і у гібридів.

Отримані результати свідчать, що гібриди обох типів відрізняються від відповідних інбредних ліній більшим середнім діаметром крохмальних гранул і більш високим середнім вмістом крохмалю в зерні, тоді як відмінності за середнім вмістом амілози в крохмалі між лініями і гібридами кукурудзи як традиційного типу, так і кукурудзи на основі мутації $s u_{l}$ несуттєві.

В ході виконання дослідів було також встановлено, що основні ознаки якості гранулярного крохмалю і у ліній і у гібридів - носіїв мутації $s u_{l}$ мають кількісну природу і вирізняються досить широкою мінливістю. У неспоріднених за походженням ліній - носіїв мутації $s u_{l}$ коливання діаметру крохмальних гранул становило $0,6 \%$, вмісту крохмалю в зерні $2,3 \%$, вмісту амілози в крохмалі - $1,7 \%$, а у гібридів - відповідно $0,8 \%$, $0,9 \%$ та $1,3 \%$ (табл. 2 ).

Таким чином, отримані результати показали, що гібриди - носії мутації $s u_{1}$ відрізняються від ліній на основі цієї мутації більш широкою мінливістю за діаметром крохмальних гранул та вмістом крохмалю в зерні і більш вузькою мінливістю за вмістом амілози в крохмалі.

Результати дисперсійного аналізу свідчать про наявність суттєвих відмінностей між різними лініями - носіями мутації $s u_{1}$ за ефектами комбінаційної здатності щодо основних ознак якості гранулярного крохмалю (табл. 3). 
Мінливість основних ознак якості гранулярного крохмалю у гібридів кукурудзи традиційного типу і гібридів - носіїв мутації $s u_{l}$ (середнє за результатами випробувань в двох екологічних зонах, 2009 р.)

\begin{tabular}{|c|c|c|c|c|c|c|}
\hline \multirow{2}{*}{$\begin{array}{c}\text { Типи } \\
\text { гібридів }\end{array}$} & \multicolumn{2}{|c|}{$\begin{array}{l}\text { Діаметр крохмаль- } \\
\text { них гранул, мкм }\end{array}$} & \multicolumn{2}{|c|}{$\begin{array}{l}\text { Вміст крохмалю в } \\
\text { зерні, \% до а.с.р. }\end{array}$} & \multicolumn{2}{|c|}{$\begin{array}{c}\text { Вміст амілози в } \\
\text { крохмалі, \% }\end{array}$} \\
\hline & $\begin{array}{l}\text { мін.- } \\
\text { макс. }\end{array}$ & середній & $\begin{array}{l}\text { мін.- } \\
\text { макс. }\end{array}$ & середній & $\begin{array}{l}\text { мін.- } \\
\text { макс. }\end{array}$ & середній \\
\hline Традиційний & $\begin{array}{l}9,8- \\
11,3\end{array}$ & 10,4 & $\begin{array}{l}68,5- \\
72,3\end{array}$ & 70,4 & $\begin{array}{c}26,1- \\
27,0\end{array}$ & 26,6 \\
\hline Мутанти $s u_{l}$ & $\begin{array}{l}5,0- \\
5,8\end{array}$ & 5 & $\begin{array}{l}37,2- \\
41,1\end{array}$ & 39,7 & $\begin{array}{l}32,0- \\
33,3\end{array}$ & 32,5 \\
\hline $\mathrm{HIP}_{0,95}$ & 0,2 & 0,2 & 0,7 & 0,7 & 0,4 & 0,3 \\
\hline
\end{tabular}

Основний вклад до дисперсії за цими ознаками вносили ефекти загальної комбінаційної здатності (ЗКЗ). Ефекти специфічної комбінаційної здатності (СКЗ) у ліній - носіїв мутації $s u_{l}$ були значно меншими, а за вмістом амілози в крохмалі - і взагалі несуттєвими.

Таблиця 3

Результати дисперсійного аналізу комбінаційної здатності ліній кукурудзиносіїв мутації $s u_{1}$ за основними ознаками якості гранулярного крохмалю, розрахунковий критерій $\mathrm{F}_{0,95}$ (середнє за результатами випробувань ліній та гібридів діалельної схеми схрещувань в двох екологічних зонах, 2009 р.)

\begin{tabular}{|c|c|c|}
\hline \multirow{2}{*}{ Ознаки } & \multicolumn{2}{|c|}{ Джерела дисперсії } \\
\cline { 2 - 3 } & ефекти 3К3 & ефекти СК3 \\
\hline Діаметр крохмальних гранул & 73,16 & 15,64 \\
\hline Вміст крохмалю в зерні & 72,58 & 30,43 \\
\hline Вміст амілози в крохмалі & 25,79 & 2,00 \\
\hline $\mathrm{F}_{\text {0,95табл. }}$ & 2,68 & 2,18 \\
\hline
\end{tabular}

Серед проаналізованих в дослідах ліній - носіїв мутації $s u_{l}$ найбільш високі ефекти ЗКЗ за діаметром крохмальних гранул і вмістом крохмалю в зерні показали лінії МС - 401 та МC - 266, а найбільш високі ефекти ЗКЗ за вмістом амілози в крохмалі - лінії МС - 11 та МC - 73 (табл. 4).

Варіанси СКЗ за діаметром крохмальних гранул і вмістом амілози в крохмалі у всіх проаналізованих ліній були дуже низькими і мало відмінними між собою. Відмінності між варіансами СКЗ у різних ліній - носіїв мутації $s u_{1}$ за вмістом крохмалю в зерні були виражено у значно більшому ступені і найбільш широкі варіанси СКЗ за цією ознакою проявили лінії МС-11 та МС-266.

Загальна оцінка генетичних компонентів дисперсії свідчить, що успадкування діаметру крохмальних гранул і вмісту крохмалю в зерні гібридами - носіями мутації $s u_{1}$ здійснюється за типом позитивного наддомінування, а успадкування вмісту амілози в крохмалі - за типом неповного домінування із суттєвим вкладом до дисперсії адитивних ефектів. 
Таблиця 4

Комбінаційна здатність ліній кукурудзи - носіїв мутації $s u_{l}$ і генетичні компоненти дисперсії за основними ознаками якості гранулярного крохмалю (середнє за результатами випробувань ліній та гібридів діалельної схеми схрещувань у двох екологічних зонах, 2009 р.)

\begin{tabular}{|c|c|c|c|c|c|c|}
\hline \multirow{2}{*}{ Лінії } & \multicolumn{2}{|c|}{$\begin{array}{c}\text { Діаметр } \\
\text { крохмальних } \\
\text { гранул }\end{array}$} & \multicolumn{2}{c|}{$\begin{array}{c}\text { Вміст крохмалю } \\
\text { в зерні }\end{array}$} & \multicolumn{2}{c|}{$\begin{array}{c}\text { Вміст амілози } \\
\text { в крохмалі }\end{array}$} \\
\cline { 2 - 7 } & $\begin{array}{c}\text { ефекти } \\
\text { ЗК3 }\end{array}$ & $\begin{array}{c}\text { варіанси } \\
\text { СК3 }\end{array}$ & $\begin{array}{c}\text { ефекти } \\
\text { 3К3 }\end{array}$ & $\begin{array}{c}\text { варіан- } \\
\text { си } \\
\text { СК3 }\end{array}$ & $\begin{array}{c}\text { ефекти } \\
\text { 3К3 }\end{array}$ & $\begin{array}{c}\text { варіанси } \\
\text { СК3 }\end{array}$ \\
\hline MC-11 & $-0,17$ & 0,02 & $-0,58$ & 1,17 & 0,31 & 0,07 \\
\hline MC-270 & $-0,04$ & 0,00 & $-0,28$ & 0,50 & 0,09 & $-0,02$ \\
\hline MC-713 & 0,07 & 0,01 & 0,09 & 0,67 & $-0,12$ & $-0,01$ \\
\hline MC-401 & 0,16 & 0,02 & 0,94 & 0,91 & $-0,42$ & 0,02 \\
\hline MC-266 & 0,15 & 0,02 & 0,74 & 1,02 & $-0,18$ & 0,05 \\
\hline MC-73 & $-0,18$ & 0,01 & $-0,92$ & 0,30 & 0,31 & $-0,02$ \\
\hline HIP 0,95 & 0,05 & & 0,25 & & 0,17 & \\
\hline H1/D & 1,93 & & 6,76 & & 0,50 & \\
\hline a & $-0,01$ & & $-0,57$ & & 0,01 & \\
\hline b & 0,85 & & 0,68 & & 0,78 & \\
\hline
\end{tabular}

Зареєстрована в дослідах кількісна мінливість основних ознак якості гранулярного крохмалю у носіїв мутації $s u_{l}$ може бути викликана трьома можливими чинниками.

Першим 3 них є грунтово - кліматичні умови вирощування [15]. Як свідчать отримані результати, в більш сприятливих умовах вирощування, які склалися в 2009 році на Устимівській дослідній станції рослинництва, у переважної більшості ліній та гібридів - носіїв мутації $s u_{I}$ спостерігався більший діаметр крохмальних гранул, більш високий вміст крохмалю в зерні і більш низький вміст амілози в крохмалі, ніж у ліній та гібридів, які вирощувалися в Дослідному господарстві "Елітне".

Поряд $з$ цим, отримані результати показали, що ефект ендоспермової мутації $s u_{1}$ за проаналізованими ознаками значно суттєвішим, ніж вплив грунтово - кліматичних умов вирощування.

Другим чинником, який викликає кількісну мінливість основних ознак якості гранулярного крохмалю у носіїв мутації $s u_{1}$, може бути множинний алелізм в цьому локусі [16]. Однак при оцінках значущості цього чиннику слід враховувати, що при створенні всіх використаних в наших дослідах ліній було застосовано лише один мутантний алель $s u_{l}$. Тому ми не вбачаємо можливості пояснення кількісної мінливості ознак якості гранулярного крохмалю саме ефектом множинного алелізму.

Нарешті, третім, найбільш вірогідним чинником кількісної мінливості ознак якості гранулярного крохмалю $є$ ефекти полігенних комплексів, 
суттєвість яких показано в регуляції як діаметру крохмальних гранул, так $\mathrm{i}$ вмісту крохмалю в зерні і амілози в крохмалі [17-18]. Результати проведених нами досліджень свідчать, що ці ефекти можуть викликати власну дисперсію за ознаками якості гранулярного крохмалю і модифікувати ефект моногенної ендоспермової мутації $s u_{1}$.

Висновки. Основні ознаки якості гранулярного крохмалю у носіїв ендоспермової мутації кукурудзи $s u_{1}$ мають кількісну природу і суттєво залежать від взаємодій ген : генотип. Діаметр крохмальних гранул і вміст крохмалю в зерні носіїв мутації $s u_{l}$ успадковуються за типом позитивного наддомінування, а вміст амілози в крохмалі - за типом неповного домінування із суттєвим вкладом до дисперсії адитивних ефектів. Виділено лінії носії мутації $s u_{1} 3$ високими ефектами комбінаційної здатності за основними ознаками якості гранулярного крохмалю.

\section{Список використаних джерел}

1. Roper H. Starch: present use and future utilization / H. Roper // Carbohydrates as organic raw material; H.Roper, F.Voragen Eds. - Wageningen : Carbohydr. Res. Assoc., 1996. - P. 17-35.

2. Starch chemistry and technology, $3^{\text {rd }}$ ed./ J. Be Miller, R. Whistler Eds.- Amsterdam - Boston - Heidelberg - London - New York - Oxford - Paris - San Diego - San Francisco - Singapore : Acad. Press, Elsevier Publ., 2009. - 900 p.

3. White P. J. Properties of corn starch / P. J. White // Specialty Corns; A. R. Hallauer Ed. - Boca Raton - London - New -York - Washington, D.C. : CRC Press, 2001. - P. 41-70.

4. Pollak L. M. Breeding for grain quality traits / L. M. Pollak, M. P. Scott // Maydica. - 1995. - Vol.50. - P. 247-257.

5. Genetic diversity and selection in the maize starch pathway / S. R. Whitt, L. M. Wilson, M. I. Tenaillon [et al.] // Proc. Natl. Acad. Sci. USA. - 2002. Vol. 99. - P. 12959-12962.

6. Nelson O. E. Starch synthesis in maize endosperm / O. E. Nelson, D. Pan // Ann. Rev. Plant Physiol. Plant Mol. Biol. - 1995. - V. 46. - P. 475-496.

7. Boyer C. D. Kernel mutants of corn / C. D. Boyer, L. C. Hannah // Specialty Corns; A.R. Hallauer Ed. - Boca Raton - London - New-York - Washington, D.C. : CRC Press, 2001. - P. 10-40.

8. Wang Y. J. Thermal and gelling properties of maize mutants from the $\mathrm{OH}-43$ inbred line / Y. J. Wang, P. White, L. Pollak // Cereal Chem. - 1992.- V.69. P.328-334.

9. Characterization of starch structures of 17 maize endosperm mutant genotypes with Oh43 inbred line background / [Y. J. Wang, P. White, L. Pollack, J.L. Jane] // Cereal Chem. - 1993. - Vol. 70. - P. 171-179.

10. James M. G. Characterization of the maize gene sugary-1, a determinant of starch composition in kernels / M. G. James, D. S. Robertson, A. M. Myers // Plant Cell. - 1995. - Vol.7. - P. 417 - 429. 
11. Доспехов Б .А. Методика полевого опыта / Б. А. Доспехов. - М.: Агропромиздат, $1985 .-351 \mathrm{c}$.

12. Методы биохимического исследования растений / [под ред. А. И. Ермакова]. - Л.: Агропромиздат, 1987. - 430 с.

13. Лакин Г. Ф. Биометрия / Г. Ф. Лакин. - М.: Высшая школа, 1973. -343 с.

14. Литун П .П. Генетика количественных признаков. Генетические скрещивания и генетический анализ / П. П. Литун, Н. В. Проскурнин.- Киев: УМК ВО, 1992.- 96 c.

15. Maize starch fine structures affected by ear developmental temperature / [ T.J. Lu, J.-L. Jane, P. L. Keeling, G. W. Singletary] // Carbohydr. Res. - 1996. Vol.282. - P. 157 - 170.

16. Molecular structure of three mutations at the maize sugary-1 locus and their allele - specific phenotypic effects / [ J. R. Dinges, C. Colleoni, A. M. Myers, M. G. James] // Plant Physiol. - 2001. - Vol. 125. - P. 1406 - 1418.

17. Quantitative trait loci affecting amylose, amylopectin and starch content in maize recombinant inbred lines / M. Sene, M. Causse, C. Damerval [ et al.] // Plant Physiol. Biochem. - 2000. - Vol. 38. - P. 459-472.

18. Wilson J. A. Genetic effects of the soft starch (h) and background loci on volume of starch granules in five maize inbreds / J. A. Wilson, D. V. Glover, W. E. Nyquist // Plant Breed. - 2000.- Vol. 119. - P. 173-176.

Установлено, что основные признаки качества гранулярного крахмала у носителей эндоспермовой мутации кукурузы $s u_{l}$ имеют количественную природу и существенно зависят от взаимодействий ген : генотип. Диаметр крахмальных гранул и содержание крахмала в зерне носителей мутации $s u_{1}$ наследуется по типу положительного сверхдоминирования, а содержание амилозы в крахмале - по типу неполного доминирования с существенным вкладом в дисперсию аддитивных эффектов. Выделены линии носители мутации $s u_{I}$ с высокими эффектами комбинационной способности по основным признакам качества гранулярного крахмала.

It have been established that the general characters of granular starch quality in the carriers of maize endospermic mutation $\mathrm{su}_{1}$ were notable as having the quantitative nature an depended under the gene: genotype interactions. Starch granules's diameter and starch content in the grain of the carriers of mutation $\mathrm{su}_{1}$ were inherited as the type of positive over-dominance, whereas the content of amylose in the starch - as the type of incomplete dominance with the significant contribution of additive effects to the variance. The inbreds - carriers of mutation $\mathrm{su}_{1}$ with the high effects of combining ability for the general characters of granular starch quality were identified. 